\title{
Isolation of Marine Bacteriophages from Sea Water
}

\author{
Tomio HidakA* \\ (Received July 23, 1971)
}

\begin{abstract}
The author carried out the isolation of marine bacteriophages from sea water and determined the morphological character of five of them. The host bacteria isolated belong to Pseudomonas (2 strains), Vibrio (2), and Flavobacterium (1). The isolated phages are highly specific to the original host and are virulent. The structure of the phage particles varies widely. Remarkable variety was observed especially in the tail structure. They are divided into three morphological groups; phage with a tail possessing a contractile sheath, phages with a long and non-contracting tail, and phages with a short tail. It is difficult to find a morphological property of marine bacteriophages in this experiment. It is certain that they vary widely in their morphology.
\end{abstract}

Information on marine bacteriophage is relatively scant. The earlier work has been reviewed by $Z_{0 B E L L}{ }^{1)}$. It will suffice to state here, however, that although bacteriophages active against a variety of enterobacteria can readily be demonstrated in polluted estuarine and coastal waters, their presence has not been demonstrated in waters remote from terrestrial contamination. Attempts to isolate phages from sea water have been successful in some cases $^{2,3}$. SPENCER ${ }^{4,5)}$ presented detailed methods for the isolation of bacteriophages from sea water and obtained seven bacteriophages active on four genera of Gram negative bacteria from the North Sea, some ten miles off the coast of Scotland. SPENCER ${ }^{6)}$ made also an interesting attempt to determine the concentration of phage particles in the water samples. According to the data, from 1 to 5 particles of phage were found in $10 \mathrm{ml}$ of water, although in one sample the concentration reached 100 particles to $10 \mathrm{ml}$ of water. Electron micrographs of one of SPENCER's phages have recently been shown by VALENTINE et al. ${ }^{7}$. More recently, WIEBE and LISTON ${ }^{8)}$ isolated a bacteriopage active against a marine Aeromonas sp. from marine mud, and described the characterization of the marine properties of the phage. CHAINA ${ }^{97}$ tested 629 bacterial cultures and bacteriophages obtained from the Indian Ocean and North Sea waters and found 10 cultures sensitive to phages. JoHNSON ${ }^{10)}$ reported also on a Vibrio-bacteriophage isolated from marine mud in the Indian Ocean.

It is hoped that further studies are being carried out on the interactions of a marine bacteriophage with a bacterium and with the physical environment in order to understand the role of bacteriophage in controlling natural bacterial populations and variation of marine bacteria. The author dealt with the isolation of marine bacteriophage systems from sea water sample collected from the Pacific Ocean, five miles off the Satuma Peninsula

* Faculty of fisheries, Kagoshima University, Shimoarata-cho, Kagoshima, Japan (日高富男: 㢈 児鳥大学水㢈学部) 
of Kyushu, Japan. The present paper describes the morphological character, plaque appearance and particle structure, of the phages isolated.

\section{Materials and Methods}

Media used. The sea water broth (SWB) contained $5 \mathrm{~g}$ polypeptone and $1 \mathrm{~g}$ yeast extract in a liter of HERBST's artificial sea water. The $\mathrm{pH}$ of the medium was adjusted to 7.6-7.8. Agar was added at $1.5 \%$ concentration for a solid medium (sea water agar, SWA). Soft SWA contained agar of $0.5 \%$ cancentration.

Isolation and microbiological test of used bacteria. The water sample was collected with steril bacteriological $\mathrm{J}-\mathrm{Z}$ water samplers from a 50 meters of depth at a station $\left(31^{\circ} 04^{\prime} \mathrm{N}-130^{\circ} 35^{\prime} \mathrm{E}\right)$. The sample was cultured on SWA plates at $20^{\circ} \mathrm{C}$ for 6 days. The representative of various colonies were picked from the agar plate cultures and purified by three consecutive streakings of isolated colonies on SWA plates. Sixty-eight cultures were obtained in the way described above. Characterization of the isolated bacteria was done using standard methods ${ }^{211}$. Identification was carried out according to the systems outlined by SHEwAN et al. ${ }^{12,13)}$ and BERGEY's Manual (7th ed. $)^{14)}$.

Demonstration of bacteriophages. This was experimented according to the indirect method described by SPENCER ${ }^{4}$. To each of a series of sterile shaking flasks was added $150 \mathrm{ml}$ of SWB together with $5 \mathrm{ml}$ of an overnight SWB culture of each of ten different bacterial strains in purified isolates and shaken for 2-3 h. After then the young cultures were mixed with $200 \mathrm{ml}$ of sample sea water which filtrated through a HA Millipore filter to remove bacteria. The mixtures were incubated with shaking 2-3 $\mathrm{h}$ and were further incubated overnight without shaking. After a brief centrifugation at $4,500 \mathrm{G}$ for 30 min, the cultures were filtered through HA Millipore filter membranes. The filtrates were spotted onto lowns prepared from the homologous bacterial culture streaking on agar plates. These preparations were incubated overnight and examined the appearance of lysis zone. All incubations in this section were done at $25^{\circ} \mathrm{C}$.

Isolation of the bacteriophages. Material from the center of clear zones developing on lawns was transferred by a platinum wire to fresh SWB cultures of the appropriate bacterium and the incculated cultures incubated a further $18 \mathrm{~h}$ at $25^{\circ} \mathrm{C}$. Each of the cultures was then filtered and a portion of the filtrate mixed with the appropriate bacterium in $3 \mathrm{ml}$ of soft SWA melted and cooled to $45^{\circ} \mathrm{C}$ and the mixture layered onto the surface of an agar plate. The double agar layer plates were incubated overnight. Single plaques arising by this method were picked and the cycle repeated three times to ensure their identity and assist purification. An initial titer of $10^{9-10}$ plaque forming units ( $\mathrm{pfu}$ ) per $\mathrm{ml}$ of bacterial culture filtrate was obtained by this method for the single phage system isolated. The phage lysates were stored at $5-8^{\circ} \mathrm{C}$. 
Electron microscopy. A $50 \mathrm{ml}$ of stock phage lysate prepared as above was centrifuged at $37,000 \mathrm{G}$ at $0^{\circ} \mathrm{C}$ in superspeed refrigerated centrifuge for $90 \mathrm{~min}$, and the pellet obtained from original suspension was resuspended in $1 \mathrm{ml}$ of $1 \%$ ammonium acetate solution. The preparations were negatively stained with phosphotungstic acid, namely, the phage suspensions were mixed with the same volume of $2 \%$ phosphotungstic acid solution at a pH of 7.2, and applied as droplets directly to the grids. Carbon-corted collodion grids of 150 mesh were used as the specimen supports. The preparations remained on the grids for 20 to $30 \mathrm{sec}$. before the excess liquid was removed with filter paper. After drying, the grids were ready for examination in the electron microscope. The grids were examined in a Hitachi, HU-11D type, electron microscope. Micrographs were taken at electronic magnification of 50,000 .

\section{Results}

Host bacteria and bacteriophages isolated. A total of 68 cultures of bacteria isolated from the sea water sample, of which 8 were sensitive to bacteriophages. The sensitive cultures belonged to the following genera; Pseudomonas (3), Vibrio (3), and Flavobacterium (2). By using the method described it was proved to be 8 phages active individually against the 8 host bacteria. Because this paper dose not have enough space to describe all of the host bacteria and the bacteriophages isolated, the author introduces on five of bacteriumphage systems for them here.

The brief characterization of the host bacteria is shown in Table 1. All of the host bacteria used in this experiment are aerobic and psychrophilic bacteria. They belong

Table 1. Brief characterization of the host bacteria.

\begin{tabular}{|c|c|c|c|c|c|c|c|c|c|c|c|c|c|c|c|c|c|c|c|}
\hline $\begin{array}{l}\text { Host } \\
\text { bacteria }\end{array}$ & $\frac{E}{E}$ & 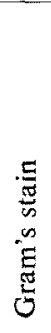 & 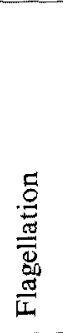 & 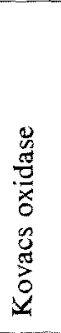 & 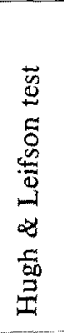 & 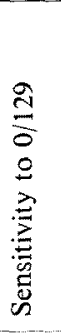 & 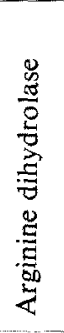 & 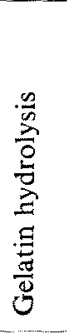 & 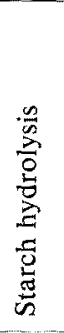 & 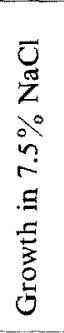 & $\begin{array}{l}0 \\
0 \\
0 \\
0 \\
0 \\
0 \\
5 \\
0 \\
0 \\
0 \\
0\end{array}$ & 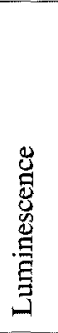 & 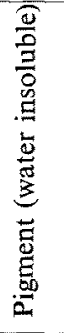 & 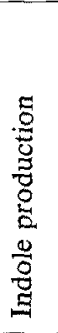 & 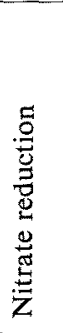 & 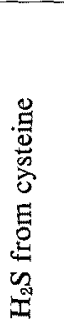 & $\begin{array}{l}\text { 苞 } \\
0 \\
\dot{>} \\
>\end{array}$ & $\begin{array}{l}\overrightarrow{\tilde{g}} \\
\stackrel{0}{0} \\
\dot{\alpha} \\
\dot{\Sigma}\end{array}$ & 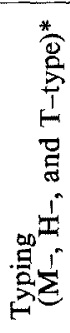 \\
\hline $06 \mathrm{~N}-21$ & $\mathrm{R}$ & - & M & + & $\mathrm{F}$ & + & + & + & + & - & - & - & - & - & + & + & - & + & $\mathrm{H}-$ \\
\hline $06 \mathrm{~N}-24$ & $\mathrm{R}$ & - & $P$ & + & NC & - & - & + & + & - & - & - & Y & - & - & - & - & - & $\mathbf{M}_{-}$ \\
\hline $06 \mathrm{~N}-34$ & $\mathrm{R}$ & - & $\mathbf{M}$ & + & $\mathrm{F}$ & + & + & + & + & - & - & - & - & + & + & - & - & + & $\mathrm{H}-$ \\
\hline $06 \mathrm{~N}-52$ & $\mathrm{R}$ & - & M & + & O & - & - & + & + & + & - & - & - & - & + & + & - & - & M- \\
\hline $06 \mathrm{~N}-58$ & $\mathrm{R}$ & - & $\mathbf{M}$ & + & 0 & - & - & + & + & + & - & - & - & - & + & + & - & - & M- \\
\hline
\end{tabular}

Key: $\mathbf{R}$, rods; $P$, peritrichous; $M$, monotrichous; $Y$, yellow; - , negative; + , positive; $O$, oxidative; $F$, fermentative; $N C$, growth with no change in reaction; $M-$, Marine type; $H-$, Halophilic type,

* Three types, Marine ( $\mathrm{M}_{-}$) type, Halophilic $\left(\mathrm{H}_{-}\right)$type and Terrestrial $(\mathrm{T}-$ ) type, were designated according to the requirement of bactereria for several kinḍs of salts in sẹa water ${ }^{15 !}$. 
to Marine type or Halophilic type dsignated by HIDAKA ${ }^{15)}$ according to the requirement of the bacteria for several kinds of salts in sea water. The five of host bacteria used belong to the following genera: $06 \mathrm{~N}-21$ and $06 \mathrm{~N}-34$, Vibrio; 06N-24, Flavobacterium; 06N-52 and $06 \mathrm{~N}-58$, Pseudomonas.

The host range of the bacteriophages was determined by spotting drops of lysates prepared on each phage on overlays containing the various bacteria isolated. Each of five bacteriophages lysed only the original host bacterium. As the phages were isolated by the indirect method, there was a possibility that they arose not from the sea water but because one of the ten bacterial cultures added was lysogenic strain. This possibility was disproved by testing the strains for lysogenicity. The bacteriophages isolated are virulent phages.

Plaque morphology. Fig. 1 show the plaque morphology of used phages. 06N-21 phage and $06 \mathrm{~N}-24$ phage form clear plaques of about $1-2 \mathrm{~mm}$ in diameter. $06 \mathrm{~N}-34$ phage and $06 \mathrm{~N}-52$ phage produce small plaques of about $1 \mathrm{~mm}$ in diameter with a turbid halo. $06 \mathrm{~N}-58$ phage give rise to larger, clearcut plaques of about $2-3 \mathrm{~mm}$ in diameter.

Structure of the phage particles. The structures of used phage particles are shown in Fig. 2, and the dimensions of its show in Table 2.

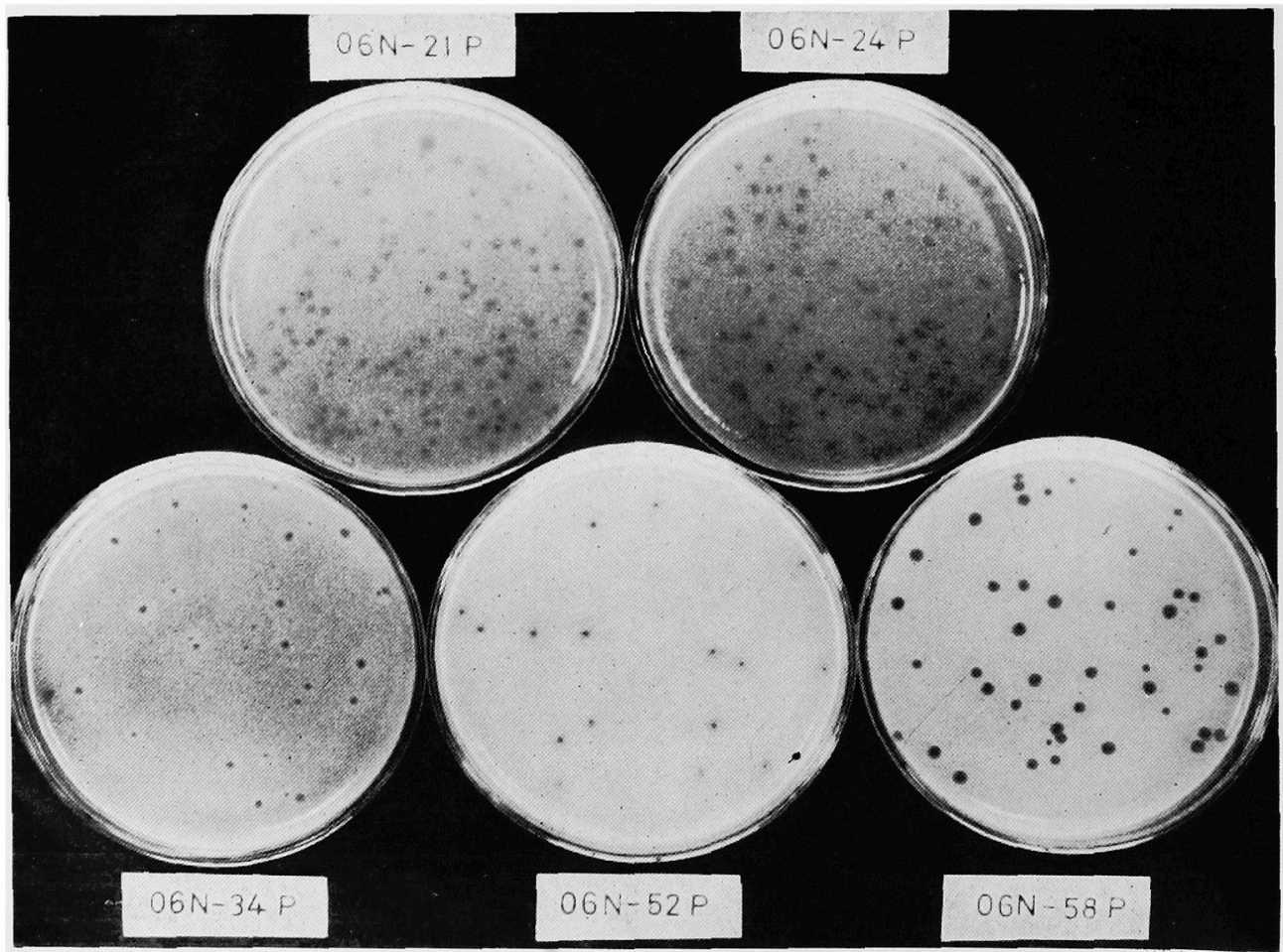

Fig. 1. Plaque morphology of the used marine bacteriophages. 


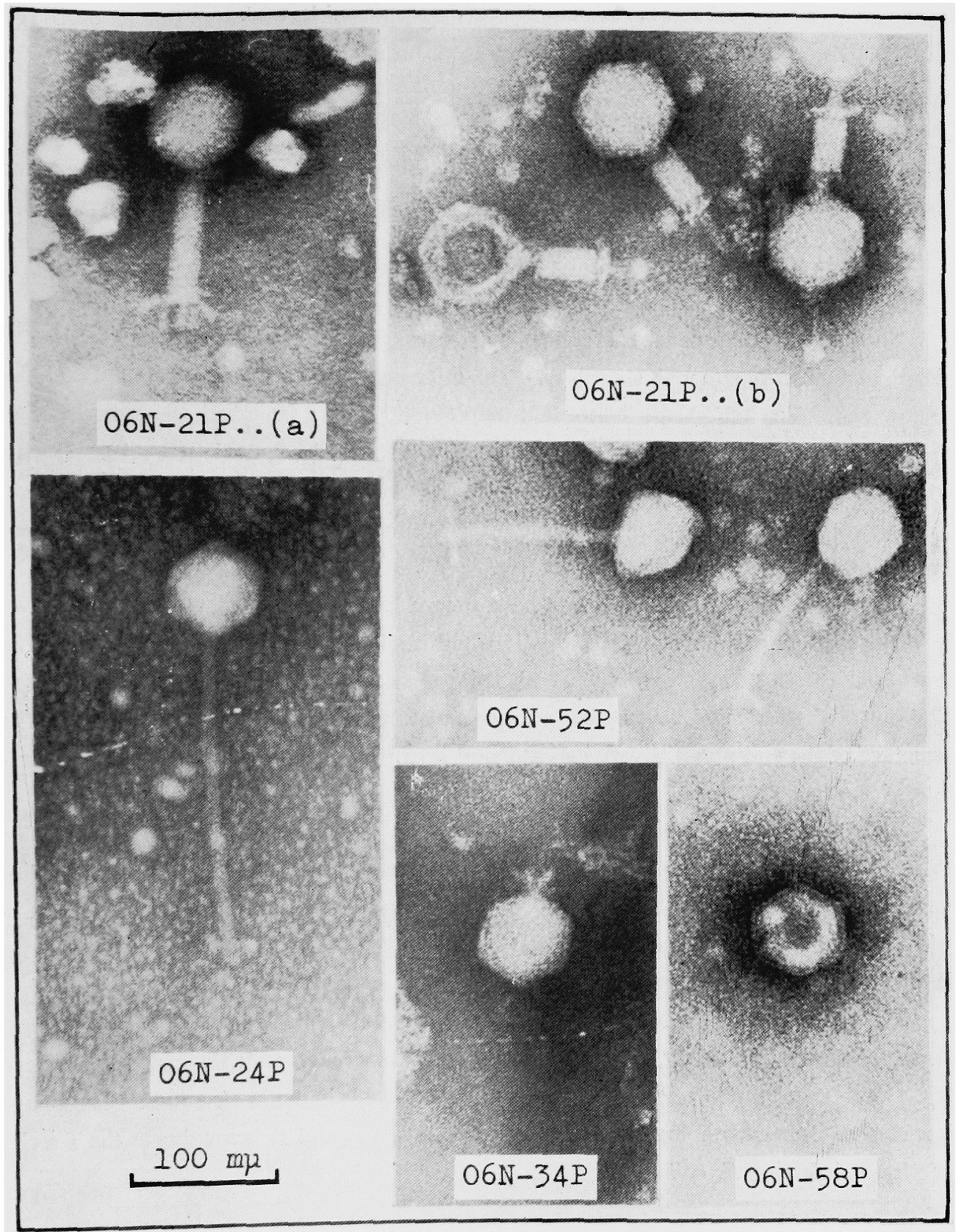

Fig. 2. Electron micrographs of the used marine phage particles negatively stained with phosphotungstic acid. $\times 200,000$. 
Table 2. Dimmensions of the phage particles used.

\begin{tabular}{c|c|cc}
\hline \hline Phages & $\begin{array}{c}\text { Size of head } \\
\text { Diameter, } \mathrm{m} \mu\end{array}$ & \multicolumn{2}{|c}{ Size of tail } \\
& 65 & $95-100$ & 22 \\
\hline $06 \mathrm{~N}-21 \mathrm{P}$ & 60 & $200-220$ & 10 \\
$06 \mathrm{~N}-24 \mathrm{P}$ & 60 & 15 & 10 \\
$06 \mathrm{~N}-34 \mathrm{P}$ & 60 & $110-120$ & 10 \\
$06 \mathrm{~N}-52 \mathrm{P}$ & 60 & 10 & 5 \\
$06 \mathrm{~N}-58 \mathrm{P}$ & & & \\
\hline
\end{tabular}

The $06 \mathrm{~N}-21$ phage consists of a head with a hexagonal outline, a tail with a contractile sheath and an end-plate with six spikes. The tail consists of an outer sheath and an inner hollow rod. The tail sheath exists in two different states; stretched, characteristics of the intact particle (Fig. 2, 06N-21P . . a), and contracted (Fig. 2, 06N-21P . b). During contraction the sheath becomes shorter and wider, thereby exposing the inner rod. Typical members of this morphological group are the T-even phages of $E$. coli $\mathrm{B}$, which are widely known and have received the most study.

$06 \mathrm{~N}-24$ and $06 \mathrm{~N}-52$ phages have a head shaped like a polyhedron, and a comparatively long and thin, non-contracting tail. This tail is slightly or considerably curved. The most characteristic feature distinguishing the phages is that their tail can not contract. The tail of these phages terminates in an end-plate with short lobate projections. The structure of the end-plates is very delicate, and it can easily be destroyed during preparation of specimens.

The particles of $06 \mathrm{~N}-34$ phage at first glance differ in their tail structure. The short tail of the phage thus consists mainly of an end-plate which is joined almost immediately (through a very short neck) with the head. The end-plate, about $10 \mathrm{~m} \mu$ in width and $4 \mathrm{~m} \mu$ in thickness, have six hexagonally arranged projections about $4 \mathrm{~m} \mu$ in width and $10 \mathrm{~m} \mu$ in length.

The particles of $06 \mathrm{~N}-58$ phage consist of a head shaped like a regular polyhedron, and a short thail of peculiar structure. The characteristic feature distinguishing the phage is the short conical tail. The short tail is comparatively simple in structure. The phage is similar in their morphology to the well-studied phage $T_{3}$ and $T_{7}$ belonging to the $T$ series of phages infecting $E$. coli $\mathrm{B}$.

\section{Discussion}

The importance of bacteriophage typing in the identification of strains of terrestrial organisms (e.g. staphylococci and the enterobacteria) is well established. The application of this technique might eventually prove equally useful in marine bacteriology. No phage was found to lyse all strains of the homologous species in the used phages. Within 
the limits of this experiment, the host-specificity of the marine phages used is very strict. The author can not find any phages due to typing within or without marine bacteria in this experiment.

The size of the phage particle itself, which largely determines its rate of diffusion through the medium; in general, small phages tend to produce large plaques, although this correlation is by no means complete. It is difficult to find a certain relation between the plaque morphology and the structure of particles of the used phages.

SMrth and KRUEGER $^{3}$ isolated a Vibrio-bacteriophage system from the mud of San Francisco Bay. Their electron micrograph of the phage is probably the first morphological study on a marine phage. The phage had a head, $95-100 \mathrm{~m} \mu$ in diameter, and a tail which was $100 \mathrm{~m} \mu$ length and $15 \mathrm{~m} \mu$ in diameter. BRADLEY ${ }^{16)}$ showed a micrograph of a phage, NCMB 384, isolated by SPENCER ${ }^{6)}$. In negative-stained preparations the phage has a polyhedral head, $60 \mathrm{~m} \mu$ in diameter, and a non-contractile tail $100 \mathrm{~m} \mu$ long, with an unusually complicated tip. VALENTINE $e t$ al. ${ }^{7}$ using electron microscopy with negative staining techniques showed one of SPENCER's phages to have a unique triangular tipped tail. WeIBE and LISTON ${ }^{8)}$ studied a bacteriophage active against a marine Aeromonas sp. isolated from a depth of $850 \mathrm{~m}$. Electron micrographs of the phage revealed to bave a hexagonal head $53 \mathrm{~m} \mu$ in diameter and a thin tail $(120 \mathrm{~m} \mu)$ with a terminal base plate. JOHNSON ${ }^{10)}$ revealed the morphology of the phage isolated by himself. The head is hexagonal and approximately $60 \mathrm{~m} \mu$ in diameter. The tail is apparently too small to be resolved in his preparation. These investigations are individual observations on some marine phages. Up to the present time, there has been no systematic study on the morphology of marine bacteriophages.

BRADLEY $^{177}$ proposed dividing bacteriophages into six morphological groups. TIKHONENKO ${ }^{18)}$ suggested to combine BRADLEY's phage groups 4 and 5 into a single group, and then divided them five main morphological groups based largely on BRADLEY's classification: (1) filamentous phages; (2) phages with analogs of a tail; (3) phages with a short tail; (4) phages with a long and non-contractile tail; and (5) phages with a tail of complex structure with a contractile sheath.

As Fig. 2 shows, marine phages vary widely in their morphology. Remarkable variety was observed in the tail structure among the phages. According to the TrKHONENKO's grouping of phage, the marine bacteriophages isolated in this experiment belong to the groups 3,4 and 5, and they are phages containing double-stranded deoxyribonucleic acid. It is difficult to find a morphological property of marine bacteriophage. More detailed studies on the morphology of marine bacteriophages will be reported elswhere. 


\section{Acknoledgements}

The author would like to thank Prof. D. Kaкiмoтo, Kagoshima University, for his helpful advice. The author also wishes to express gratitude to Captain, Mr. K. TAKAHASHI and crews of Nansei Maru, Training Ship of Kagoshima University, for their very able and kind assistance with the sampling of sea water. The assistance of Messrs. J. Uehara and Y. Atuchi, Faculty of Medicine, Kagoshima University, with the electron microscopy is deeply appreciated.

\section{References}

1) C. E. ZoBell: Marine Microbiology, 82 pp., Chronica Co., Waltham, Mass. (1946).

2) A. E. Kriss and E. A. RukrNa: Rept. U.S.S.R. Acad. Sci., 57, 833-836 (1947).

3) L. S. SMith and A. P. KRUEGER: J. gen. Physiol., 38, 161-168 (1954).

4) R. SPENCER: Nature, 175, 690-691 (1955).

5) R. SPENCER: J. Bacteriol., 79, 614 (1960).

6) R. SPEnCER: in "Symposium on Marine Microbiology" (C. H. Oppentrermer, ed.), 350-365, Charles. C. Thomas, Springfield, Illinois (1963).

7) A. F. Valentine, P. K. Chen, R. R. Colwell, and G. B. Chapman: J. Bacteriol., 91, 819-822 (1966).

8) W. J. Wiebe and J. Liston: Marine Biol. 1, 244-249 (1968).

9) P. N. Chaina: J. gen. Microbiol., 41, Proceedings xxv (1965).

10) R. M. Johnson: J. Arizona Acad. Sci., 5, 28-33 (1968).

11) W. F. Harrigan and M. E. MCCANCE: Laboratory Methods in Microbiology, 51 pp., Academic Press, New York (1966).

12) M. S. Henderie and J. M. Shewan: in "Identification Methods for Microbiologists, Part A" (B. M. Grbbs and F. A. Skinner, ed.), 1-7, Academic Press, New York (1966).

14) N. BAIN and J. M. SHEwaN:" in "Identification Methods for Microbiologists, Part B" (B. M. Gibbs and D. A. Shapton, ed.), 79-84, Academic Press, New York (1968).

14) R. S. Breed, E. G. D. Mtrray, and N. R. Smith: Bergey's Manual of Determinative Bacteriology, 7th ed., 35 pp., Wilkins Co., Baltimore (1957).

15) T. Hidaka and M. SakaI: Bull. Misaki Marine Biol. Inst. Kyoto Univ., No. 12, $125-149$ (1968).

16) D. E. Bradley: J. R. Microsc. Soc., 84, 257-316 (1965).

17) D. E. Bradley: Bacterial Rev. 31, 230-314 (1967).

18) A.S. TIKhonenko: Uitrastructure of Bacterial Viruses (Translated from Russian by B. HaIGH). 29 pp., Plenum Press, New York (1970). 